\title{
Pharmacognosy of Science for the Protection and Survival of Nature and Man
}

\author{
Elvira Kovac-Besovic ${ }^{*}$, Adnan Besovic, Azra Besovic and Salih Saračević
}

Faculty of Pharmacy, University of Sarajevo, Bosnia and Herzegovina

*Corresponding author: Elvira Kovac-Besovic, Faculty of Pharmacy, University of Sarajevo, Bosnia and Herzegovina, Tel: +387-33233639; E-mail: elvirakb@hotmail.com

Received date: April 07, 2018; Accepted date: April 13, 2018; Published date: April 18, 2018

Copyright: (c) 2018 Kovac-Besovic E, et al. This is an open-access article distributed under the terms of the Creative Commons Attribution License, which permits unrestricted use, distribution, and reproduction in any medium, provided the original author and source are credited.

\begin{abstract}
Pharmacognosy as a science of natural medicinal raw materials and drugs of natural origin is a science that protects nature and affects the survival and protection of man. From the earliest times, man was exploring everything that nature provides. With the development of science and technology, research into natural raw materials, as well as those with healing activity, was perfected. The obtained results could reliably be used in official pharmacopoeia, medicine and dentistry. With the development of computer technology, there has been more detailed information on the use of natural medicinal raw materials through Phytotherapy, which is increasingly being applied.
\end{abstract}

All these studies indicate that pharmacognosic studies with the goal of using natural medicinal substances and medicines of natural origin must not be called alternative medicine, but it is the same as all other medicines that are only adapted to the nature of natural raw materials.

Keywords: Pharmacognosy; Science; Nature; Man; Phytotherapy

\section{Introduction}

The protection and survival of nature, and hence the very man, is an unwritten rule and law that has lasted from the beginnings of life on planet Earth. The vulture had to protect its natural environment so that it could survive. From his natural environment, he took food, but also raw materials for the protection of his body, the construction of his housing facility, the production of various tools for work. He took raw materials and then for the production of weapons of protection from animals, and later, unfortunately, from the very man himself. By developing the intellectual capabilities of man, science, with it and technology, developed, but they grew and became increasingly diverse needs of man himself. The advancement of mankind is a constant rise of ideas, a constant search for an unknown, constant search for answers to discovering a series of secretive nature and life. The search for a man for many gave him a series of answers and discoveries in the period before the new era, and continued and lasts for as many as 20 centuries or heavier 2000 years. We are now in the $21^{\text {st }}$ century, are we wondering and do we know where we are?

The twenty-first century is the obvious development of science, and very rapid advancement of technology. In the first position of this advancement, the development of information technologies that seem to have taken an irreplaceable place in all aspects of human life. It has become the way and motto of life and has created an almost complete dependence of man on the application in everyday work and life. Undoubtedly, these technologies have helped a lot; they help, and should in the future just help a man to accomplish a lot of tasks easier. But man is still a living being, living a complex and at the same time simple but also a unique living organism. An organism that thinks, speaks, walks, becomes ill, heals himself and finally, communicates with all other living plant and animal beings, as well as appearances on Earth, with the power of reason.

However, in this stampede of technological discoveries and reliefs, man somewhat forgets what is most important to him. He forgets to preserve his natural environment in order to have a permanent source for his life, work, preservation of good health and, if necessary, receive a medicine in case of illness, that is, allow for his survival.

In all this, in the shadow of lifelong technology, constantly, as a protector of man, the pharmacognosy of medicine and a scientific field that studies natural medicinal raw materials and medicines of natural origin [1-3].

\section{Material and Methods}

This brief review of the nature and significance of Pharmacognosy as a scientific area was presented using textbook and other literature data. The aim of this essay is to ease this small text by highlighting the need for a constant presence of Pharmacognosy in the everyday need for the use of natural medicinal raw materials. This need can be preventative in protecting and maintaining good human health, it can be a cure for the treatment of the disease, and finally, for its fast and quality recovery after treatment. However, Pharmacognosy, although a man is not aware of it, is nevertheless constantly present in his everyday life [3-5]

\section{Results and Discussion}

Pharmacognosy involves the research and study of the presence of chemically defined and pharmacologically active substances in natural raw materials of plant, animal and mineral branch. The largest percentage of representation is raw material of plant origin. The significance of this focused research is that the importance of a particular plant species as a medicinal, food or industrial raw material 
is determined solely on the basis of its chemical composition. It is not the same whether the plant contains alkaloids and which alkaloids, saponins and which saponins, coumarins, flavonoids, whether fat or essential oils, vitamins, enzymes and a whole range of all types of chemicals are present. It is less important whether these substances or products are found in the root, leaf, flower, bark, fruit and seeds. Given that pharmacognosy is only relevant to the part of the plant in which the substances are present, the pharmacognosy carries only the herbal part. In this way, the plant material is protected, which is not hampered by further growth, development and reproduction. By maintaining plant material, permanent annual harvesting of raw materials and the invention of druggist material is enabled. The result is the protection of the natural habitat, and indirectly the protection of the survival of life, primarily human and animal life.

Pharmacy as an integral part of the medical profession is only able to deal with this complex research according to the rules of pharmacognosy. Thus, it accepts great responsibility for finding, studying and applying medicinal raw materials in the rich environment of diverse flora and fauna. The maintenance and duration of the entire natural mass is possible only with the presupposition of the perfect harmony.

A man as an integral part of nature. It is completely dependent on nature in the sense that it acts on it, and the return and nature affects man. When a man cuts off a forest tree or rebuilds a river to build a hydroelectric power plant, he changes the environment to his advantage-to obtains wood raw material or electricity. However, with this work, man disturbs the natural harmony. In the absence of forests, atmospheric circulation is disturbed, which leads to the appearance of unusual winds and other phenomena. Stopping the flow of the river will create a lake that will evaporate more in the atmosphere creating a stronger fog. In his new environment, a person feels immensely affected or adapted or suffers from their consequences. There are invisible chemical reactions that manifest in dysfunction in various areas. A man in his normal state survives thanks to harmonization in the functioning of certain organisms of a living organism. In this respect, life-chemical reactions occur as causes and consequences of the work of each organ. In a normal, healthy organism they work together and one complement each other chemically very different substances.

If, for any reason and cause, there is a disorder of chemical reactions in the organism, there is a violation of the normal state, a phase of health disorder or disease occurs. A man then searches for a cure, seeks a chemical substance that will help his, currently disturbed chemistry, return to normal, which is manifested by healing.

That's what he said Paracelzus: "Nature is a great harmony in which there is only a continuous organism, and a disease occurs when this harmony breaks down in the human body".
As everything is in nature, so are the metabolic processes of man and plants connected in terms of replenishment. It is a mistake to say that for every disease there is a plant that will be treated. Why, because it does not cure the plant, does not cure either the leaf, nor the flower nor any plant part? Treat the appropriate substance that the plant material can produce. It is thus correct to state that for each disease there is an appropriate medicinal chemical substance in the plant material. So the plant part appears only as the carrier of that substance, its depot.

Using the methods of pharmacognostic analysis, combining certain techniques and methods, accurate data processing, one learns about the quality of certain natural medicinal raw materials. It further opens the possibility of their use in official pharmacy, medicine and stomatology as phytotherapy [4-6].

\section{Conclusion}

The basic and most important conclusion that should be constantly promoted when natural medicinal raw materials are concerned is that their use should not be characterized as an alternative medicine. Pharmacognostic research is based on and applies the laws of basic scientific disciplines with the application of all modern methods of research. The results obtained indicate the justification of application in official pharmacy and medicine, not as an alternative, but as an additional therapy or prevention.

\section{Conflict of Interest}

The authors declare no conflict of interest.

\section{References}

1. Mascherpa P (1949) Trattato di Farmakologiae Farmacognosia, Editore Ulrico Hoepli, Milano.

2. Tucakov J (1963) Farmakognozija, Naučna knjiga Beograd.

3. Kuštrak D (2005) Farmakognozija Fitofarmacija, Golden MarketingTehnička knjiga, Zagreb p: 615.

4. Kovač-Bešović E (2001) Metodeu farmakognoziji, Sarajevo-Publishing, Sarajevo.

5. Samuelsson G (2004) Drugs of Natural Origin. A Textbook of Pharmacognosy $5^{\text {th }}$ revised edition, Apotekar Societeten Swedish Pharmaceutical Society.

6. Heinrich M, Barnes J, Gibbons S, Williamson M (2004) Fundamentals of Pharmacognosy and Phytotherapy, Churchill Livingstone, Edinburgh London New York Oxford Philadelphia St. Louis, Toronto. 